\title{
ヒバリの 黑變
}

匫山元一

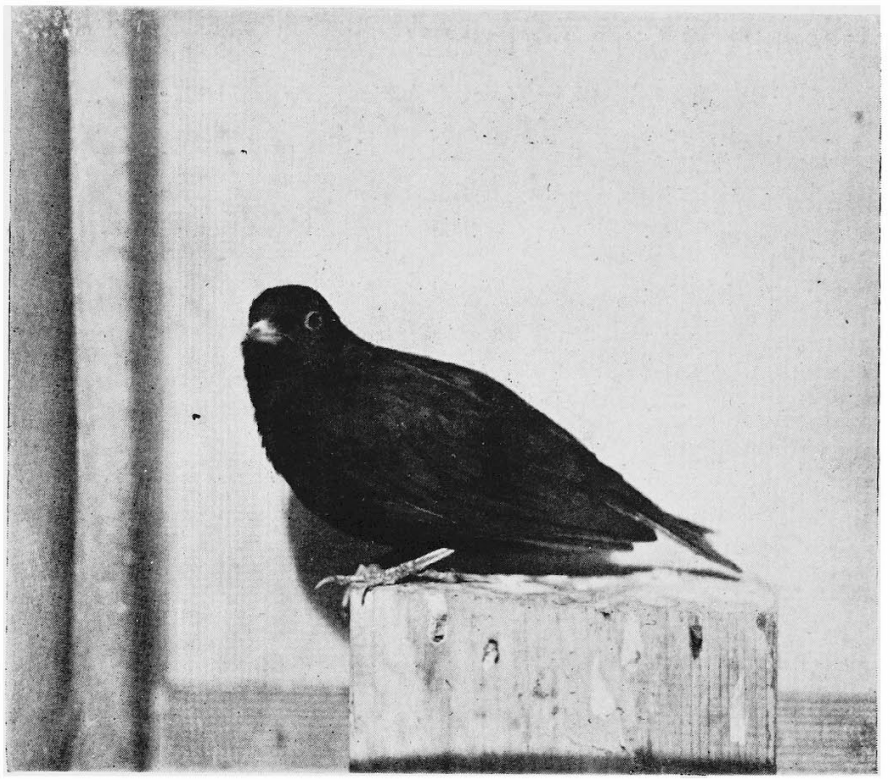

第 19 圖 ヒバリの黑變（伺育中に變色）

ヒバリの黑變の 1 例下の如く報告す

飼充者任所氏名

岐阜縣为茂郡蜂屋村

日汇:井 利雄 (目下飼育中)

袔育のヒバリは鸰育開始 4 年のもの, 昭和 15 年春より黑變し始め夏季 迄に全く黑變したるもの. 